\title{
The Utilization of Health Services by the Elderly in Lubuk Buaya Health Center in Padang City
}

\author{
Sri Oktarina ${ }^{1, *}$, Sri Mindayani ${ }^{1}$, Wirzam Harir $\mathrm{HS}^{1}$ \\ ${ }^{1}$ Public Health Faculty Baiturrahmah University West Sumatera, Indonesia \\ "Corresponding Author. Email: srioktarina@fkm.unbrah.ac.id
}

\begin{abstract}
The morbidity rate is one indicator to measure the degree of health. In 2015, the morbidity rate for the elderly in Indonesia was $28.62 \%$. However, the percentage of urban elderly morbidity rate of $26.89 \%$. This study aims to determine factors related to the utilization of health services by the elderly in the Public Health Service Area in Koto Tangah District, Padang City. The research design is quantitative with a across sectional study. The population in this study is elderly who are life in the Public Health Service Area in Koto Tangah District. The number of the population is 3901 elderlies aged 60 years. The sample number is 94 elderlies. The results of the research showed $44.7 \%$ of the elderly did not utilize health services. $34.0 \%$ of the elderly with a lack of knowledge, $12.8 \%$ of the elderly do not have health insurance, and $40.4 \%$ of the elderly have a lack of perception about illness. The statistical test obtained the knowledge and perception of illnes, $\mathrm{p}$ value are 0,000 respectively but health insurance ownership $\mathrm{p}$ value is 0,184 . The results of the analysis showed that there was a significant relationship between knowledge and perception of illness to the utilization of health services. There is no significant relationship between health insurance ownership to utilization of health services.
\end{abstract}

Keywords: elderly, utilization, health services, ownership of health insurance

\section{INTRODUCTION}

According to the World Health Organization (WHO) that the average UHH in the world is 71.4 years and Indonesia is ranked 120th in the world at 69.1 years [1]. The success of development is the ideals of a nation that can be seen from the improvement of living standards and life expectancy $(\mathrm{UHH})$. Changes in demographic structure are caused by an increase in the elderly population (elderly) with a decrease in mortality and a decrease in the number of births [2]. The morbidity rate is one indicator used to measure the health status of the population. In 2015 the morbidity rate for the elderly was $28.62 \%$, meaning that for every 100 elderly people there were 28 of them experiencing illness. Based on [3], the percentage of the elderly population living in urban areas for outpatient treatment is higher than the elderly living in rural areas. This may be closely related to health facilities that are generally more complete available in urban areas than in rural areas. According to [1] $8.1 \%$ of the world's population. According to data [3], the number of elderly people in Indonesia reaches 21.68 million, equivalent to $8.49 \%$ of the total population of Indonesia, the number of elderly people in West Sumatra, which is $8.8 \%$ of the total population in Sumatra West and the number of elderly in the city of Padang, which is $6.4 \%$ of the total population in the city of Padang. Based on data from the Lubuk Buaya Puskesmas from the last 3 years, it is known that there was a significant decline in elderly visits at the Lubuk Buaya
Puskesmas with a visit rate of $24.6 \%$ in 2014 to $2.83 \%$ in 2015 while in 2016 there was a significant increase in elderly visits with a visit rate of $24.4 \%$ (Profile of the Lubuk Buaya Health Center, 2015) in [4].

The Lubuk Buaya Puskesmas is a puskesmas located in Koto Tangah District with four working areas, namely Lubuk Buaya, Pasia Nan Tigo, Batang Kabung Ganting, and Parupuk Tabing. This Lubuk Buaya Puskesmas has the highest number of visits among other Puskesmas in the city of Padang, amounting to 388,901 people (Profile of the Lubuk Buaya Public Health Center, 2015) in [4].

Based on the above background, the researcher is interested in conducting research on factors related to the utilization of health services by the elderly in the working area of the Lubuk Buaya Public Health Center in Padang City.

\section{METHOD}

This research uses a quantitative study using adesign cross sectional. The study was conducted in the working area of the Lubuk Buaya Health Center, Koto Tangah District, Padang City. When the study was conducted in May to August 2017. The population in this study were all elderly people aged 60 years and over and the sample in this study were 94 elderly. Primary data were obtained through a questionnaire given to the elderly in the working area of the Lubuk Buaya Public Health. The sample was selected by random sampling technique, data collected by interview using a questionnaire. Data were analyzed by bivariate test 
Table 3. Relationship of Healthcare Ownership with Utilization of Health Services

Distribution of Utilization of Health Services, Knowledge Health Insurance Ownership and Perception about Illness.

Table 1. Distribution of Utilization of Health Services, Knowledge, Health Insurance Ownership and Perception About Illness

\begin{tabular}{ccc}
\hline Variable & f & Percentage \\
\hline Utilization of Health Services & 42 & 44,7 \\
Yes & 52 & 55,3 \\
& & \\
Knowledge & 32 & 34,0 \\
Less & 62 & 66,0 \\
Good & & \\
& & \\
& & 12,8 \\
Health Insurance Ownership & 12 & 87,2 \\
Not Have & 82 & \\
Have & & 40,4 \\
& & 59,6 \\
Less & 38 & 100,0 \\
Good & 56 & \\
Account & 94 & \\
\hline
\end{tabular}

Based on table 1, it can be seen that $(44.7 \%)$ respondents did not utilize health services, less than half $(34.0 \%)$ of respondents have less knowledge, less than half of the $12.8 \%$ elderly do not have health insurance, less than half $40,4 \%$ of elderly have less pain perception.

Relationship between Elderly Knowledge Levels to Utilization of Health Services.

Table 2. Relationship between Elderly Knowledge Levels to Utilization of Health Services

\begin{tabular}{cccccccc}
\hline \multirow{2}{*}{$\begin{array}{c}\text { Knowledge } \\
\text { Level }\end{array}$} & \multicolumn{4}{c}{ Utilization Level } & \multicolumn{2}{c}{ Good } & \multicolumn{2}{c}{ Total } & $p$ \\
& $\mathrm{f}$ & $\%$ & $\mathrm{f}$ & $\%$ & $\mathrm{f}$ & $\%$ & \\
\cline { 1 - 7 } Lack & 28 & 87,5 & 4 & 12,5 & 32 & 100 & 0,000 \\
Higher & 14 & 22,6 & 48 & 77,4 & 62 & 100 & \\
Account & 42 & 44,7 & 52 & 55,3 & 94 & 100 & \\
\hline
\end{tabular}

Based on Table 3, it can be seen that $87.5 \%$ of respondents whose level of knowledge is lacking, do not utilize health services, are higher than those of low knowledged respondents $(22.6 \%)$. Judging from the statistical test results obtained $p$ value of 0,000 meaning $\mathrm{p} \leq 0.05$, it can be concluded that there is a significant relationship between the levels of knowledge with the level of utilization in the working area of Lubuk Buaya Public Health Centre.

Relationship of Healthcare Ownership with Utilization of Health Services

\begin{tabular}{|c|c|c|c|c|c|c|c|}
\hline \multirow{3}{*}{$\begin{array}{l}\text { Healthcare } \\
\text { Ownership }\end{array}$} & \multicolumn{4}{|c|}{ Utilization of Health } & \multirow{2}{*}{\multicolumn{2}{|c|}{ Total }} & \multirow{3}{*}{$\begin{array}{l}p \\
\text { value }\end{array}$} \\
\hline & \multicolumn{2}{|c|}{ Lack } & \multicolumn{2}{|c|}{ Higher } & & & \\
\hline & f & $\%$ & $\mathrm{f}$ & $\%$ & $\mathrm{f}$ & $\%$ & \\
\hline Not have & 8 & 66 & 4 & 33 , & 1 & 10 & 0,18 \\
\hline Have & 3 & 41 & 4 & $\begin{array}{l}3 \\
58,\end{array}$ & $\begin{array}{l}2 \\
8\end{array}$ & $\begin{array}{l}0 \\
10\end{array}$ & 4 \\
\hline & 4 & 5 & 8 & 5 & 2 & 0 & \\
\hline Accoun & 4 & 44, & 5 & 55 , & 9 & 10 & \\
\hline $\mathrm{t}$ & 2 & 7 & 2 & 3 & 4 & 0 & \\
\hline
\end{tabular}

Based on Table 4 shows that $66.7 \%$ of respondents who do not have health insurance levels of utilization of health services are lacking, and by $41.5 \%$ of respondents who has a level of health insurance utilization of health services is lacking. Viewed from the statistical test results obtained $p$ value of 0.184 meaning $\mathrm{p}>0.05$, it can be concluded that there is no significant relationship between health insurance ownership and the level of service utilization in the working area of Lubuk Buaya Public Health Centre. Relationship between Ilness Perception and Health Service Utilization

Table 4. Relationship between Ilness Perception and Health Service Utilization

\begin{tabular}{|c|c|c|c|c|c|c|c|}
\hline \multirow{3}{*}{$\mathrm{s}$} & \multicolumn{4}{|c|}{ Utilization } & \multirow{2}{*}{\multicolumn{2}{|c|}{ Total }} & \multirow{4}{*}{$\begin{array}{l}p \\
\text { value }\end{array}$} \\
\hline & \multicolumn{2}{|c|}{ Less } & \multicolumn{2}{|c|}{ Good } & & & \\
\hline & $\mathrm{f}$ & $\%$ & $\mathrm{f}$ & $\%$ & $\mathrm{f}$ & $\%$ & \\
\hline Less & 32 & 84,2 & 6 & 15,8 & 38 & 100 & \\
\hline Good & 10 & 17,9 & 46 & 82,1 & 36 & 100 & \\
\hline Jumlah & 42 & 44,7 & 52 & 55,3 & 94 & 100 & \\
\hline
\end{tabular}

Based on the Table 5 shows that there are $84.2 \%$ or more than half of respondents who have less ill health perception, the level of health service utilization is less, and $179 \%$ of respondents had good pain perception but lack of utilization of health services. Judging from the statistical test results obtained $p$ value of 0,000 means that $\mathrm{p} \leq 0.05$, it can be concluded that there is a significant relationship between pain perception and the level of utilization in the working area of Lubuk Buaya Public Health Center.

\section{DISCUSSION}

1. Health Service Utilization

Based on the research results it is known that the proportion of elderly people who use health services is $55.3 \%$ and $44.7 \%$ who do not use health services. This study is in line with research conducted [5] showing that more than half of the elderly $(64.4 \%)$ utilize health services in Sumber Rejo Health Center.

According to Levey and Loomba (2011) in [6], what is 
meant by the utilization of health services is every effort carried out individually or jointly in an organization to maintain and improve health, prevent, treat diseases and restore one's health, family, group and community.

Compare with research has researched by [7] is defference while it is known that less than half $(37.7 \%)$ of the elderly out of $55.3 \%$ who use health services, utilize Puskesmas as a treatment to health services. Puskesmas (Community Health Center) is a functional implementation unit that functions as a center for health development, a center for fostering community participation in the health sector as well as a first-level health service center that organizes its activities in a comprehensive, integrated and sustainable manner in a community residing in certain regions. According to Permenkes Number 75 of 2014, Puskesmas is a health service facility that organizes efforts public health and first-level individual health efforts, with more emphasis on promotive and preventive efforts, to achieve the highest degree of public health in the working area [8]. Distance factor also affects the utilization of health centers as an effort to treat disease. Puskesmas Lubuk Buaya with its strategic location makes the elderly choose to use the puskesmas in their treatment efforts. In addition, the treatment for Puskesmas can come from mass media information, advice from people around, personal or family experience for visits to Puskesmas as a health service provider. Therefore, health workers are expected to be able to increase the promotion media, especially the invitation to check health services. The promotional media can be in the form of print media such as posters, leaflets or electronic media such as radio and television.

\section{Knowledge level}

Based on the results of the study, it is known that less than half $(34.0 \%)$ of the elderly have less knowledge about the utilization of health services. This is in line with the research by Hartini (2013) in [9] in the work area of the Mandastana Community Health Center in Mandastana District that less than half $(19.3 \%)$ had less knowledge about health services.

Knowledge is the result of human sensing or the result of knowing someone about objects through objects through their senses (eyes, nose, ears and so on). Knowledge is a very important domain for the formation of a person's actions (over behavior) [10].

Based on the research it is known that more than half $(61.7 \%)$ of the elderly do not know under what conditions should check their health regularly. More than half (57.4\%) of the elderly did not know what was obtained in health services, and less than half $(45.7 \%)$ of the elderly did not know what the purpose of the health service facilities were. According to the researchers' assumptions, the elderly's ignorance of information regarding the condition of regular health checks, the type of services obtained and the purpose of the existence of health service facilities is due to the lack of promotional media for the elderly.

The condition of the elderly who have experienced a decrease in sensory function, one of which is the sense of sight has resulted in the promotion of media in the form of posters being ineffective, therefore it is expected that health workers can provide information related to health services through counseling at least once a month which can be done inside the building or outside the building.

\section{Health Insurance Ownership}

Based on the results of the study, it is known that the majority $(87.2 \%)$ of the elderly have health insurance and a small proportion $(12.8 \%)$ of the elderly do not have health insurance. This study is in line with [11] study that more than half $(64.9 \%)$ of the elderly have health insurance and utilize health services.

According to [12] that health insurance is a tool that helps the community to continue to perform health care without having to be burdened with economic / financial problems. Health insurance is a very important role in the view of public health, especially when sick, so that community needs for health services are met and health financing can be guaranteed.

Based on the research, it is known that most (92.7\%) of the elderly have the type of social health insurance and a small proportion $(7.3 \%)$ of the elderly have the type of commercial health insurance. The high social security ownership is the impact of the government's target to achieve Universal Health Coverage (UHC) or overall health coverage for the population of Indonesia on 1 January 2019. The Government in every year BPJS Health targets the number of residents who participated in 2017 to grow to 223 million people [13].

\section{Illness Perception}

Based on the results of the study, it can be seen that more than half $(40.4 \%)$ of the elderly have less pain perception. This is in line with research [9] that more than half $(39.6 \%)$ of elderly people have a negative perception of illness. According to [14] states that someone in the process of perception will determine which messages will be received. Perception is considered to determine how someone will choose, gather and arrange, and give meaning which will then affect the responses (behaviors) that will emerge from him. Perception will also influence someone to take a decision as a reaction to a problem, because every decision requires the interpretation and evaluation of information [15].

Based on research, it is known that $24.5 \%$ of the elderly assume that if they get sick without treatment / go to health services, the symptoms will disappear by themselves. According to thetheory Health Belief Model in [16] that perception of severity tends to be related to the utilization of one's medical services.

Based on the research, it is known that $26.6 \%$ of the elderly assume that complaints of pain that are felt are the same as complaints of feelings felt by others. Each individual has a different way of healing the disease, even though the same health problems. In general, decisions are made based on individual judgment or may be assisted by other people or families who have a hereditary trust to 
overcome the disorder.

5. The Relationship between the Level of Knowledge and the Utilization of Health Services

Based on the results of the study, that $22.6 \%$ of respondents had good levels of knowledge, the level of utilization of health services was less, compared with $12.5 \%$ of respondents who had less knowledge levels but the level of utilization of health services was good.

Statistical test results obtained $p$ value of 0,000 meaning $p$ $<0.05$, it can be concluded that there is a significant relationship between the level of knowledge with the level of utilization of health services in the working area of Lubuk Buaya Puskesmas, Koto Tangah District, Padang City 2017. The results of this study are in line with research conducted by Sebayang (2006) in [17] states that there is a significant relationship between community knowledge and the utilization of health services.

The elderly's lack of knowledge about the utilization of health services results in a lack of understanding of the elderly in the utilization of health services. This limited knowledge will have an adverse impact on health maintenance. The elderly's knowledge of the benefits of this health service can be

obtained from personal experience in their daily lives. For example, by attending posyandu activities, the elderly will get counseling about how to live healthy with all the limitations or health problems inherent in them. With this experience, the knowledge of the elderly will increase, which is the basis for forming attitudes and can encourage interest in the elderly to always come to participate in the Posyandu for the elderly each month.

\section{The Relationship between Health Insurance}

Ownership and the Utilization of Health Services

Based on the results of the study, it was found that $41.5 \%$ of respondents who had health insurance tended to have less utilization of health services, compared to $33.3 \%$ of respondents who did not have health insurance. Statistical test results obtained $p$ value of 0.184 meaning $p>0.005$, it can be concluded that there is no significant relationship between health insurance ownership and the level of utilization of health services in the Work Area of the Lubuk Buaya Health Center, Koto Tangan District, Padang City in 2017.

The results of this study are the same as the study [18], states that health insurance ownership has no significant relationship to the utilization of health services. The results of the analysis of health insurance ownership do not affect the utilization of health services, this is because even though the community has health insurance, but most of it cannot be used for health services at the Lubuk Buaya Health Center because the Health Center only serves participants of health insurance from BPJS that are in accordance with designated health services, so that some people who do not comply with these conditions prefer to be public patients without utilizing the BPJS card they already have.
7. The Relationship between Sickness Perception and Health Service Utilization

Based on the research results, it can be seen that as many as $17.9 \%$ of respondents who have a good perception of illness, the level of utilization of health services is less, compared to as much as $15.8 \%$ of respondents who have less ill perception but the level of utilization of health services is good. Statistical test results obtained $p$ value of 0,000 meaning $\mathrm{p}<0.005$, it can be concluded that there is a significant relationship between pain perception with the level of utilization of health services in the working area of Lubuk Buaya Puskesmas, Koto Tangah District, Padang City 2017. This study is in line with Savitri's research ( 2011) in [11], states that there is a significant relationship between respondents with perceptions of ill health and respondents with perceptions of ill health in the utilization of health services. The perception of illness is almost the same as the concept of public health. Based on research, it is known that $26.6 \%$ of respondents think that pain complaints are felt the same as complaints that are felt by other people.

In this case, it is expected that health workers can provide counseling to the elderly to form the correct perception of the concept of health and sickness, besides it is expected that the health center can form a healthy paradigm for the community, especially the elderly in the working area of Lubuk Buaya Puskesmas. In addition, the elderly family is expected to be able to model good behavior in treatment such as taking medication to health services because the behavior of the closest relatives of the elderly will influence the elderly to take advantage of health services.

\section{CONCLUSION}

Less than $50 \%$ the elderly did not utilize health services, lack of knowledge about the utilization of health services and a poor perception of illness. Moreover, just $12.8 \%$ of the elderly, do not have health insurance in the area working of the Lubuk Buaya Health Center, Koto Tangah District, Padang City. Base on statistic test, there is a significant relationship between the level of knowledge and the perception of illness with utilization of health services in the working area of the Lubuk Buaya Health Center, Koto Tangah District, Padang City. However, There is no significant relationship between the ownership of health insurance with the utilization of health services in the working area of the Lubuk Buaya Puskesmas in Koto Tangah District, Padang City.

\section{RECOMMENDATIONS}

1 It is expected that health workers can add to the promotional media, especially an invitation to check health services. At the same time providing information related to health services through counseling at least once a month which can be done outside or inside the building. 
2 Public Health Center must increase the socialization of the health service program in order to increase the elderly's insight into the importance of health care treatment so as to increase the interest of the elderly in utilizing health services.

3 Health workers are expected to be able to provide counseling to the elderly to form the correct perception of the concept of illness.

4 It is expected that the elderly family can exemplify good behavior in treatment such as taking medication to the health service.

5 It is expected that the elderly family shows an attitude of care, patience and attention to the elderly, especially the elderly who are no longer independent.

\section{REFERENCES}

[1] Organization World Health, World health statistics 2016: monitoring health for the SDGs sustainable development goals. World Health Organization, 2016.

[2] R. I. Balitbang Kemenkes, "Riset kesehatan dasar; RISKESDAS," Jakarta Balitbang Kemenkes RI, vol. 2013, pp. 110-119, 2013.

[3] Badan Pusat Statistik Provinsi Sumatera, Sumatera Barat dalam angka. 2015.

[4] Dinas Kesehatan Kota Padang, "Profil kesehatan kota Padang tahun 2014," Padang Dinas Kesehat. Kota Padang, 2015.

[5] Z. Saam and S. Wahyuni, "Psikologi keperawatan," Jakarta Rajawali Pers, 2012.

[6] T. A. Radito, “Analisis Pengaruh Disiplin Kerja, Lingkungan Kerja, dan Jaminan Sosial terhadap Produktivitas Kerja pegawai," J. Bisnis, Manajemen, dan Akunt., vol. 3, no. 2, 2016.

[7] W. I. Mubarak and N. Chayatin, "Ilmu kesehatan masyarakat: teori dan aplikasi," Jakarta Salemba Med., vol. 393, 2009.

[8] Kementerian Kesehatan, "Peraturan Menteri Kesehatan Republik Indonesia Nomor 75 Tahun 2014 tentang Pusat Kesehatan Masyarakat," Jakarta Kementeri. Kesehat., 2014.

[9] A. Primanita, "Hubungan antara Persepsi tentang Sakit dengan Pemanfaatan Pelayanan Kesehatan oleh Peserta Jaminan Kesehatan Masyarakat di Puskesmas Gunungpati Kota Semarang." Universitas Negeri Semarang, 2011.

[10] S. Notoatmodjo, "Kesehatan masyarakat," Jakarta: Rineka Cipta, 2007.
[11] N. S. Wahyuni, "Faktor-Faktor yang Berhubungan dengan Pemanfaatan Pelayanan Kesehatan di Puskesmas Sumber Rejo Kota Balikpapan Provinsi Kalimantan Timur Tahun 2012," AWSAccessKeyId= AKIAIWOW YYGZ2Y53UL3A\&Expires $=$ $1533197103 \&$ Signature $=$ Ad\% 2F2b1vloCA 1EUaN\% 2Fieq 8 SzA1U4\% 3D\&response-contentdisposition= inline $\% \quad 3 B \% \quad 20 f i l e n a m e \% \quad 3 D F i l e \_p e m a n f a a t a n$ kesehatan_di_puskesmas.pdf, 2012.

[12] W. Adisasmito, "Kebijakan standar pelayanan medik dan diagnosis related group (DRG), kelayakan penerapannya di Indonesia," Fak. Kesehat. Masy. Univesitas Indones. Jakarta, 2008.

[13] info BPJS, "BPJS Kesehatan." HYPERLINK "https://bpjs-kesehatan. go. id" https://bpjs-kesehatan. go. id ..., 2017 .

[14] B. Budioro, "Pengantar Pendidikan (Penyuluhan) Kesehatan Masyarakat," Manaj. PKM. Ed. ke-2. Balai Penerbit UNDIP, pp. 103-116, 2002.

[15] S. P. Robbins and T. A. Judge, "Perilaku organisasi (Organizational behavior)," Jakarta: Salemba Empat, 2008.

[16] M. Edberg, Essentials of health behavior. Jones \& Bartlett Publishers, 2013.

[17] L. Amalia, "Hubungan Faktor Pemungkin dengan Perilaku Pencarian Pengobatan Anak Jalanan di Kota Bekasi Tahun 2017," Bul. Penelit. Kesehat., vol. 46, no. 2, pp. 119-128, 2018.

[18] Wahyuni Sari, "Qualitative research method: Theory and practice,” Jakarta: Salemba Empat, 2012. 